\title{
Urgensi Pancasila Sebagai Ideologi Negara
}

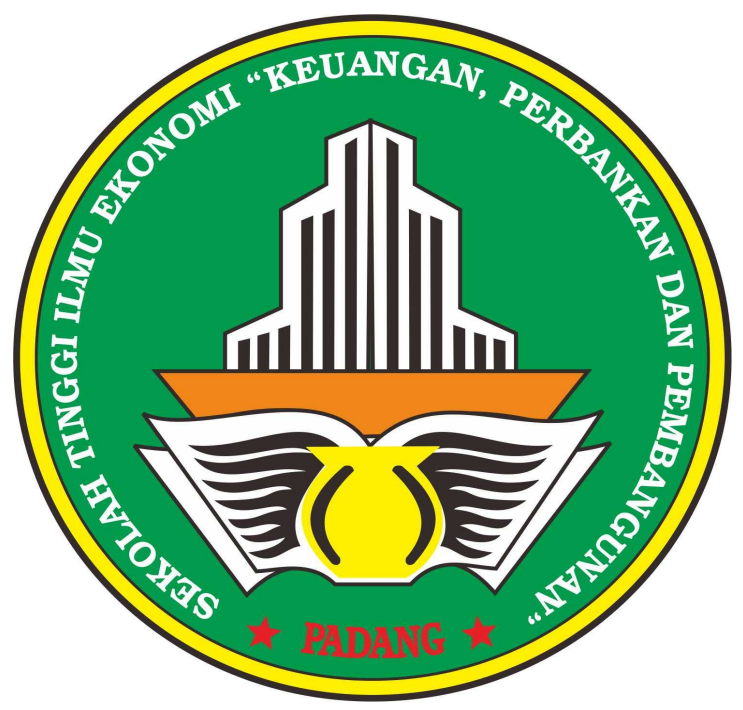

Nama : Putri Wulandari

Prodi : Management 2

Nim : 20220075

Dosen Pngampu : Laurensius Arliman,SE,SH,MH. MKn

AKBP STIE "KBP" PADANG

PADANG SUMATERA BARAT(2020) 


\section{PENDAHULUAN}

\section{Latar Belakang}

Pancasila sebagai dasar filosofi serta idieologi bangsa dan negara indonesia bukan terbentuk secara mendadak dan bukan hanya diciptakan oleh seseorang yang datangyang terjadi pada idieologi idieologi lain di dunia, namun terbentuknya pancasilamelalui proses yang cukup panjang dalam sejarah bangsa indonesia. Secara kualitas pancasila sebelum disahakan menjadi dasar filosofi negara nilai-nilai telah ada dan berasal dari bangsa Indonesia sendiri yang berupa nilai-nilai adat istiadat, kebudayaandan nilai nilai religius.Bangsa Indonesia terkenal sebagai bangsa yang besar danheterogen. Disebut bangsa yang besar karena jumlah penduduknya urutankeempat terbanyak setelah RRC, Amerika Serikat dan India.Indonesia juga bangsa yang heterogen karena terdiri atas banyak suku bangsa dengan berbagai macam agama, budaya, bahasa dan adat istiadat.Kita patut bersyukur bahwa bangsa yang besar dan heterogen ini bersatudalam naungan Negara KesatuanRepublik Indonesia. Banyak bangsa bangsa yang besar dalam sejarahnya hancur karenatidak mampu mempertahankan semangat persatuan dan kesatuan. Contohnya adalah UniSoviet dan Yugoslavia.Mengapa bangsa Indonesia mampu mempertahankan persatuandan kesatuan? salah satu jawaban adalah karena kita telah sepakat Pancasila sebagaidasar negara dan ideologi nasional Indonesia. Nilai-nilai luhur Pancasila merupakan kesepakatan bersama dan menjadi titik temu antarkelompok dan golongan masyarakat. Sebagai ideologi negara, yang terkandung di dalamnya diterima dijadikan acuan 
bersama dalam kehidupan berbangsa dan bernegara. Oleh karena itu, kita perlu memelihara dan mempertahankan Pancasila sebagai ideologi bangsa indonesia Ideologi sendiri memiliki fungsi yang sangat sentral bagi suatu negara, di mana fungsi dari ideologi sendiri adalah sebagai sesuatu yang memperkuat dan memperdalam identitas rakyatnya (Prof. W. Howard Wriggins). Dari pernyataan tersebut, maka dapat dikatakan bahwa ideologi adalah identitas dari suatu bangsa. Ideologi memiliki peran dalam mempersatukan keberagaman yang ada dalam masyarakat supaya dapat terbentuknya kehidupan berbangsa dan bernegara yang baik.Dari paparan tersebut, maka dapat terlihat betapa pentingnya ideologi bagi setiap bangsa. 


\section{Pembahasan}

Urgensi Pancasila sebagai Ideologi Negara

Pancasila sebagai ideologi negara menghadapi berbagai bentuk tantangan.Salah satu tantangan yang paling dominan dewasa ini adalah globalisasi. GlobalisasiEra saling keterhubungan antara masyarakat suatu bangsa dan masyarakat bangsa yang lain sehingga masyarakat dunia menjadi lebih terbuka. Dengan demikian,kebudayaan global terbentuk dari pertemuan beragam kepentingan yang mendekatkan masyarakat dunia. Sastrapratedja menengarai beberapa karakteristikkebudayaan global sebagai berikut :a. Berbagai bangsa dan kebudayaan menjadi lebih terbuka terhadap pengaruh timbal balik.

b. Pengakuan akan identitas dan keanekaragaman masyarakat dalam berbagaikelompok dengan pluralisme etnis dan religius.

c. Masyarakat yang memiliki ideologi dan sistem nilai yang berbeda bekerjasama dan bersaing sehingga tidak ada satu pun ideologi yang dominan.

d. Kebudayaan global merupakan sesuatu yang khas secara utuh, tetapi tetap bersifat plural dan heterogen.

e. Nilai-nilai hak asasi manusia (HAM), kebebasan, demokrasi menjadi nilainilaiyang dihayati bersama, tetapi dengan interpretasi yang berbeda-beda (Sastrapratedja,2001: 26--27). 
Fase-fase perkembangan globalisasi itu adalah sebagai berikut:

a. Fase embrio; berlangsung di Eropa dari abad ke-15 sampai abad ke-18 dengan munculnya komunitas nasional dan runtuhnya system transnasional Abad Tengah

b. Fase pertumbuhan yang meliputi abad ke-18 dengan ciri pergeseran kepadagagasan negara kesatuan, kristalisasi konsep hubungan internasional, standarisasikonsep kewarganegaraan.

c. Fase take off yang berlangsung dari 1870 sampai pertengahan 1920 yang ditandaidengan diterimanya konsep baru tentang negara kebangsaan, identitas dankepribadian nasional, mulai masuknya negara-negara non- Eropa ke dalammasyarakat internasional.

d. Fase perjuangan hegemoni yang dimulai 1920 sampai dengan pertengahan 1960yang ditandai dengan meningkatnya konflik internasional dan ideologis, sepertikapitalisme, sosialisme, fasisme, dan nazisme, dan jatuhnya bom atom yangmenggugah pikiran tentang masa depan manusia yang diikuti terbentuknyaPerserikatan Bangsa-bangsa (PBB).

e. Fase ketidakpastian; berlangsung dari 1960--1990 ditandai dengan munculnyagagasan dunia ketiga, proliferasi nuklir, konsepsi individu menjadi lebih kompleks,hak-hak kewarganegaraan semakin tegas dirumuskan, berkembangnya media globalyang semakin canggih.

f. Fase kebudayaan global; fase ini ditandai oleh perubahan radikal di Eropa Timurdan 
Uni Soviet (runtuhnya dominasi komunisme di beberapa negara), berakhirnya perang dingin, dan melemahnya konfrontasi ideologi (Sastrapratedja, 2001: 49-50) urgensi pancasila sebagai dasar negara, dapatmenggunakan 2 metode mendiskusikan, yaitu kelembagaan) dan sumber daya manusia (pribadi / sumber daya manusia). Pilih institusi yang membentuk dan mengatur negara yang terkait dengan nilai pancasila sehingga negara Indonesia memenuhi syarat negara, yang menjamin terwujudnya tujuan negara atau terpenuhinya tujuan nasional yang bermuara untuk terwujudnya masyarakat adil dan makmur. Sedangkan sumber daya manusia terletak pada 2 aspek, yaitu pada orang-orang yang memegang jabatan pada pemerintahan yang memegang nilai-nilai pancasila murni dan kesekuen dalam pemenuhan tugas dan tanggung jawabnya dan formulasi kebijakan negara akan menghasilkan kebijakan yang mendorongawantahkan kepentingan negara.

Esensi dan Urgensi Pancasila sebagai Ideologi Negara

Pancasila sebagai dasar negara berperan sebagai pedoman bagi bangsa Indonesia yangmenuntun kita dalam bersikap. Penerapan esensi Pancasila sebagai ideologi negara meliputihal-hal sebagai berikut:

a.Sila Ketuhanan Yang Maha Esa, diwujudkan dalam bentuk semangat toleransiantarumat beragama.

b.Sila Kemanuasiaan Yang Adil dan Beradab, diwujudkan penghargaan terhadappelaksanaan Hak Asasi Manusia (HAM) di Indonesia. 
c.Sila Persatuan Indonesia, diwujudkan dalam mendahulukan kepentingan bangsa dannegara daripada kepentingan kelompok atau golongan, termasuk partai.

d.Sila Kerakyatan yang Dipimpin oleh Hikmat Kebijaksanaan dalamPermusyawaratan/Perwakilan, diwujudkan dalam mendahulukan pengambilankeputusan berdasarkan musyawarah daripada voting.

e.Sila Keadilan Sosial bagi Seluruh Rakyat Indonesia, diwujudkan dalam bentukmemperkaya diri atau kelompok karena penyalahgunaan kekuasaan itulah yangmenjadi faktor pemicu terjadinya korupsi.

Pancasila sebagai dasar dan ideologi negara Indonesia merupakan seperangkat nilai yang menjadi pandangan hidup (way of life) bagi negara Indonesia. Kondisi itu meniscayakan bahwa fondasi bernegara dan praktik kehidupan berbangsa dan bernegara harus berlandaskan nilai-nilai yang terkandung di dalam Pancasila. Konsensus cerdas para pendiri negara tersebut berangkat dari sebuah paham kebangsaan yang terbentuk dari kesamaan nasib, sepenanggungan, dan sejarah serta adanya cita bersama untuk menjadi bangsa yang bersatu, berdaulat, adil, dan makmur dalam sebuah negara kesatuan. Adanya prinsip bersatu dalam perbedaan membuat Pancasila menjadi semakin kuat dan layak sebagai sebuah ideologi bagi negara Indonesia yang khas dengan keanekaragamannya. Konsep persatuan yang ideal dengan mengkondisikan setiap warga negara hidup berdampingan dan gotong royong tanpa menghilangkan identitas suku bangsa, adat istiadat, ras, ataupun agama 
Pancasila menjadi sangat penting bagi bangsa Indonesia karena Pancasila memiliki beberapa kedudukan dalam kehidupan berbangsa dan bernegara di Indonesia.Kedudukan itu seperti Pancasila sebagai jiwa bangsa Indonesia,Pancasila sebagai kepribadian bangsa Indonesia, Pancasila sebagai pandangan hidup bangsa Indonesia, Pancasila menjadi dasar negara,Pancasila sebagai sumber dari segala hukum yang ada di Indonesia,Pancasila sebagai perjanjian luhur bangsa Indonesia ketika mendirikan negara, dan Pancasila sebagai cita-cita bangsa. Kedudukan inilah yang menjadikan Pancasila menjadi sangat penting bagi bangsa Indonesia. Kedudukan ini juga dapat diartikan bahwasannya Pancasila merupakan suatu landasan bagi bangsa Indonesia dalam melaksanakan segala aspek yang menyangkut kehidupan berbangsa dan bernegera. Selain itu, Pancasila juga berfungsi sebagai penunjuk arah dalam kehidupan bernegara Indonesia. Sama seperti kapal tanpa kompas, yang tidak tahu akan kemana arah arus membawanya, Republik ini juga akan sama seperti itu apabila tidak adanya penunjuk arah,yaitu Pancasila.Pancasila juga mengandung nilai-nilai sejarah di dalamnya karena Pancasila merupakan suatu perjanjian yang dibuat oleh para pendiri bangsa ini ketika mendirikan Republik Indonesia ini. Hal-hal inilah yang membuat Pancasila memiliki fungsi dan juga kedudukan yang sangat penting bagi bangsa Indonesia.

Dengan fungsi dan juga kedudukan yang sangat penting dalam kehidupan berbangsa dan bernegara, Pancasila haruslah dapat dilestarikan oleh setiap komponen bangsa Indonesia. 


\section{Penutup}

Ideologi memiliki posisi yang sangat penting bagi setiap bangsa. Posisi penting ini dikarenakan ideologi peranan sebagai arah atau pedoman bagi bangsa untuk mencapai tujuannya masingmasing. Selain itu, peran lain yang dimiliki oleh ideologi adalah sebagai alat untuk mencegah terjadinya konflik sosial dalam masyarakat agar setiap masyarakat dapat hidup dalam ketentraman dan juga memiliki rasa solidaritas yang tinggi. Peranan lain dari ideologi adalah sebagai alat pemersatu suatu bangsa. Setiap bangsa tentu saja memiliki keberagaman baik dalam suku,bahasa,adat-istiadat,kebudayaan, dan lain sebagainya. Ideologi memiliki peran dalam mempersatukan keberagaman yang ada dalam masyarakat supaya dapat terbentuknya kehidupan berbangsa dan bernegara yang baik.Dari paparan tersebut, maka dapat terlihat betapa pentingnya ideologi bagi setiap bangsa. 


\section{DAFTAR PUSTAKA}

Darmini Roza dan Laurensius Arliman S Peran Pemerintah Daerah Di Dalam Melindungi Hak Anak Di Indonesia, Masalah-Masalah Hukum, Volume 47, Nomor 1, 2018.

Laurensius Arliman S, Komnas HAM dan Perlindungan Anak Pelaku Tindak Pidana, Deepublish, Yogyakarta, 2015.

Laurensius Arliman S, Penguatan Perlindungan Anak Dari Tindakan Human Trafficking Di Daerah Perbatasan Indonesia, Jurnal Selat, Volume 4, Nomor 1, 2016.

Laurensius Arliman S, Problematika Dan Solusi Pemenuhan Perlindungan Hak Anak Sebagai Tersangka Tindak Pidana Di Satlantas Polresta Pariaman, Justicia Islamica, Volume 13, Nomor 2, 2016.

Laurensius Arliman S, Pelaksanaan Perlindungan Anak Yang Tereksploitasi Secara Ekonomi Oleh Pemerintah Kota Padang, Veritas et Justitia, Volume 2, Nomor 1, 2016.

Laurensius Arliman S, Kedudukan Ketetapan MPR Dalam Hierarki Peraturan PerundangUndangan Di Indonesia, Lex Jurnalica, Volume 13, Nomor 3, 2016.

Laurensius Arliman S, Komnas Perempuan Sebagai State Auxialiary Bodies Dalam Penegakan Ham Perempuan Indonesia, Justicia Islamica, Volume 14, Nomor 2, 2017.

Laurensius Arliman S, Peranan Pers Untuk Mewujudkan Perlindungan Anak Berkelanjutan Di Indonesia, Jurnal Ilmu Hukum Tambun Bungai, Volume 2, Nomor 2, 2017.

Laurensius Arliman S, Mewujudkan Penegakan Hukum Yang Baik Untuk Mewujudkan Indonesia Sebagai Negara Hukum, Jurnal Hukum Doctrinal, Volume 2, Nomor 2, 2017. 
Laurensius Arliman S, Participation Non-Governmental Organization In Protecting Child Rights In The Area Of Social Conflict, The 1st Ushuluddin and Islamic Thought International Conference (Usicon), Volume 1, 2017.

Laurensius Arliman S, Partisipasi Masyarakat Dalam Pembentukan Perundang- Undangan Untuk Mewujudkan Negara Kesejahteraan Indonesia, Jurnal Politik Pemerintahan Dharma Praja, Volume 10, Nomor 1, 2017, https://doi.org/10.33701/jppdp.v10i1.379.

Laurensius Arliman S, Peran Komisi Perlindungan Anak Indonesia Untuk Mewujudkan Perlindungan Anak, Jurnal Respublica Volume 17, Nomor 2, 2018.

Laurensius Arliman S, Menjerat Pelaku Penyuruh Pengrusakan Barang Milik Orang Lain Dengan Mempertimbangkan Asas Fungsi Sosial, Jurnal Gagasan Hukum, Volume 1, Nomor 1, 2019.

Laurensius Arliman S, IImu Perundang-Undangan Yang Baik Untuk Negara Indonesia, Deepublish, Yogyakarta, 2019.

Laurensius Arliman S, Isdal Veri, Gustiwarni, Elfitrayenti, Ade Sakurawati, Yasri, Pengaruh Karakteristik Individu, Perlindungan Hak Perempuan Terhadap Kualitas Pelayanan Komnas Perempuan Dengan Kompetensi Sumber Daya Manusia Sebagai Variabel Mediasi, Jurnal Menara Ekonomi: Penelitian dan Kajian Ilmiah Bidang Ekonomi, Volume 6, Nomor 2, 2020.

Laurensius Arliman S, Pendidikan Kewarganegaraan, Deepublish, Yogyakarta, 2020.

Laurensius Arliman S, Makna Keuangan Negara Dalam Pasal Pasal 23 E Undang-Undang Dasar 1945, Jurnal Lex Librum, Volume 6, Nomor 2 Juni 2020, http://dx.doi.org/10.46839/lljih.v6i2.151.

Laurensius Arliman S, Kedudukan Lembaga Negara Independen Di Indonesia Untuk Mencapai Tujuan Negara Hukum, Kertha Semaya Journal Ilmu Hukum, Volume 8, Nomor 7, 2020. 
Laurensius Arliman S, Pelaksanaan Assesment Oleh Polres Kepulauan Mentawai Sebagai Bentuk Pelaksanaan Rehabilitasi Bagi Pecandu Dan Korban Penyalahgunaan Narkotika, Jurnal Muhakkamah, Volume 5, Nomor 1, 2020.

Laurensius Arliman S, Aswandi Aswandi, Firgi Nurdiansyah, Laxmy Defilah, Nova Sari Yudistia, Ni Putu Eka, Viona Putri, Zakia Zakia, Ernita Arief, Prinsip, Mekanisme Dan Bentuk Pelayanan Informasi Kepada Publik Oleh Direktorat Jenderal Pajak, Volume 17, No Nomor, 2020.

Larensius Arliman S, Koordinasi PT. Pegadaian (Persero) Dengan Direktorat Reserse Narkoba Polda Sumbar Dalam Penimbangan Barang Bukti Penyalahgunaan Narkotika, UIR Law Review, Volume 4, Nomor 2, 2020, https://doi.org/10.25299/uirlrev.2020.vol4(1).3779.

Laurensius Arliman S, Tantangan Pendidikan Kewarganegaraan Pada Revolusi 4.0, Ensiklopedia Sosial Review, Volume 2, Nomor 3, 2020.

Muhammad Afif dan Laurensius Arliman S, Protection Of Children's Rights Of The Islamic And Constitutional Law Perspective Of The Republic Of Indonesia, Proceeding: Internasional Conference On Humanity, Law And Sharia (Ichlash), Volume 1, Nomor 2, 2020.

Otong Rosadi danLaurensius Arliman S, Urgensi Pengaturan Badan Pembinaan Idelogi Pancasila Berdasarkan Undang-Undang Sebagai State Auxiliary Bodies yang Merawat Pancasila dalam Perspektif Hak Asasi Manusia, Prosiding Konferensi Nasional Hak Asasi Manusia, Kebudayaan dan Tujuan Pembangunan Berkelanjutan Indonesia pada Masa Pandemi Covid-19: Tantangan untuk Keilmuan Hukum dan Sosial Volume 1, Universitas Pancasila, Jakarta, 2020. 